\title{
KESIMETRISAN DALAM SISTEM DEMONSTRATIVA BAHASA MANDAILING
}

\author{
Namsyah Hot Hasibuan \\ Fakultas Ilmu Budaya Universitas Sumatera Utara \\ e-mail: namsyah@gmail.com
}

\begin{abstract}
Abstrak
Penelitian ini bertujuan mendeskripsikan sistem demonstrativa dalam bahasa Mandailing. Data diperoleh dari penutur asli dalam komunikasi sehari-hari. Analisis data dilakukan dengan pengklasifikasian ekspresi demonstrative berdasarkan teori Levinson kemudian dideskripsikan penggunaannya berdasarkan pengamatan di lapangan dan penjelasan informan. Hasil penelitian sebagai berikut. Pertama, terdapat tiga jenis jarak relatif pengacuan objek dalam bahasa Mandailing. Pengacuan objek dalam tiga jenis jarak relatif tersebut menggunakan ekspresi demonstrativa tertentu. Kedua, ekspresi demonstrativa setiap jenis jarak relatif memiliki bentuk dasar yang sama. Hal itu menunjukkan adanya hubungan yang bersifat simetris di antara ekspresi-ekspresi demonstrativa. Objek yang relatif dekat dengan penutur diacu menggunakan ekspresi demonstrativa berkomponen on. Objek yang relatif jauh dengan penutur tetapi dekat dengan mitra tutur diacu menggunakan ekspresi berkomponen $i$. Objek yang lokasinya jauh dari penutur dan mitra tutur pengacuannya menggunakan ekspresi berkomponen odu.
\end{abstract}

Kata kunci: ekspresi demonstrativa, jarak relatif, hubungan simetris

\section{SYMMETRY IN THE DEMOSTRATIVE SYSTEM IN THE MANDAILING LANGUAGE}

\begin{abstract}
This study aims to describe the demonstrative system in the Mandailing language. The data were collected from native speakers in their daily communication. They were analyzed by classifying demonstrative expressions based on Levinson's theory and their uses were described in accordance with field observations and informants' explanation. The results of the study are as follows. First, there are three types of relative distances for object reference. The object reference in the three types of relative distances uses a particular demonstrative expression. Second, a demonstrative expression for each relative distance has the same base. This shows that there is a symmetric relationship among demonstrative expressions. The object relatively close to the speaker is referred to by a demonstrative expression using the element on. The object relatively distant from the speaker but it is close to the addressee is referred to by a demonstrative expression using the element $i$. The object relatively distant from the speaker and the addressee is referred to by a demonstrative expression using the element odu.
\end{abstract}

Keywords: demonstrative expressions, relative distances, symmetric relationship

\section{PENDAHULUAN}

Demonstarativa (demonstratives) termasuk unsur penting dalam bahasa. Hal itu dapat dilihat, misalnya, dalam penggunaan bahasa tanpa kehadirannya. Akan terasa adanya kejanggalan atau kendala 
dalam berkomunikasi. Sebagai contoh, unsur ini pada tuturan Yang ini boleh Engkau ambil tidak dapat dihilangkan karena ketidakhadirannya pada tuturan tersebut akan membuat mitra tutur tidak mengetahui secara jelas benda mana yang boleh diambilnya. Kejanggalan dan kendala akibat penghilangan unsur bahasa (demonstrativa) seperti itu tampaknya terantisipasi juga oleh Huang (2007:132) dengan menyebut bahwa melakukan komunikasi melalui wahana bahasa di antara sesama penggunanya tidak dapat berjalan secara efektif dan efisien tanpa kehadiran demonstrativa di dalamnya. Diperoleh juga dari penjelasannya bahwa demonstrativa, sebagai bagian dari kajian deiksis, merupakan fenomena universal yang terdapat pada semua bahasa manusia. Penjelasan yang menguatkan hal terakhir terdapat juga dalam Klijs (2013:6) yang menyebutkan bahwa kata jenis tertentu bisa tidak ditemukan pada semua bahasa, tetapi, demonstrativa tidak demikian. Pada semua bahasa yang tercatat, demonstrativa terdapat di dalamnya. Namun, pada masing-masing bahasa tersebut terdapat perbedaan dalam sistem demonstrativanya (Gawronska, 2007:39).

Urgensi peranan demonstrativa dan dapat ditemukannya demonstrativa dalam semua bahasa, seperti dinyatakan oleh ketiga ahli di atas, mendasari dilakukannya penelitian ini. Penelitian ini berfokus pada sistem demonstrativa yang terdapat dalam bahasa Mandailing. Rincian lanjut dari fokus adalah pembicaraan tentang tiga hal yang terdapat dalam sistem demonstrativanya, yakni: (1) bentuk-bentuk ekspresi demonstrativa dalam sistem demonstrativa bahasa Mandailing; (2) bagaimanakah pembedaan bahasa Mandailing terhadap bentuk-bentuk ekspresi demonstrativanya; dan (3) bagaimanakah bentuk-bentuk ekspresi demonstrativa bahasa Mandailing digunakan.

Demonstrativa pada prinsipnya termasuk bagian dari kajian deiksis, tepatnya deiksis tempat karena bentuk-bentuk yang tergolong ke dalamnya menginformasikan tentang lokasi atau jarak sesuatu kepada peserta tutur (Jarbou, 2012:103). Tentang hal ini, Levinson (1983:62-79) pernah memberi gambaran fungsional deiksis tempat. Dari gambarannya diperoleh pengertian bahwa deiksis tempat berkenaan dengan ihwal penentuan lokasi sesuatu atau objek dalam hubungannya dengan titik taut (anchorage point) pada saat tuturan. Titik taut itu dapat berupa objek atau titik pengacuan yang penentuannya dengan skala ukuran yang pasti. Disebutkan bahwa penentuan objek pada tempat deiktis sifatnya apabila ditautkan dengan lokasi partisipan berada pada saat tuturan. Partisipan yang dimaksud (dengan memperhatikan contoh yang diberikannya (Kabul is four hundred miles West of here)) adalah penutur - dengan alasan bahwa jarak 400 mil yang dimaksud pada contoh tersebut merupakan jarak antara, apabila Kabul ditautkan dengan here, lokasi penutur berada pada saat tuturan (Huang, 2007:149). Oleh karenanya, terkait dengan ihwal tempat, yang menjadi pusat adalah lokasi tempat penutur berada pada saat tuturan. Lokasi penutur merupakan titik tumpuan dalam menginformasikan lokasi sesuatu atau objek yang dimaksudkan. Penentuan lokasi sesuatu berpedoman pada cara dengan menautkannya pada lokasi penutur berada pada saat tuturan. Dalam kajian deiksis tempat, penutur adalah pusat deiksis (deictic centre). Artinya, sesuatu yang menyangkut konsep tempat didasarkan pada perspektif dengan menjadikan penutur sebagai pusat orientasi (egocentric way (Levinson, 1983:63), egocentric system (Huang, 2007:149)).

Namun, menurut Levinson (1983:64), di luar kelaziman itu, penitiktautan dapat juga terjadi kepada partisipan selain penutur. Pendasaran perspektif semacam itu, menurut Levinson (1983:82-4), perlu dibedakan dengan perspektif yang menjadikan objek (seperti televisi, mobil) sebagai 
pusat orientasi tempat (object-centred way). Ihwal lain yang diperoleh dari Levinson (2004:42) adalah bahwa pengekspresian deiksis tempat terjadi dalam lingkup demonstrativa (yang terdiri dari pronomina demonstrativa (demonstrative pronouns), adjektiva demonstrativa (demonstratives adjectives), adverbia demonstrativa (demonstrative adverbs)) dan verba gerak (motion verbs). Dengan demonstrativa, relevansinya yang jelas terkait dengan penginformasian jarak jauh-dekatnya sesuatu (proximal-distal dimension) kepada partisipan tutur, sedangkan verba gerak bertalian dengan penginformasian arah gerakan dalam hubungannya dengan partisipan tutur pada saat tuturan.

Pronomina demonstrativa dimaksudkan untuk jenis yang fungsinya sebagai penunjuk dan pengganti nomina, bukan sebagai modifikator (Kridalaksana, 1982:108) pada kata/frase. Adjektiva demonstrativa, dari segi bentuk, sama dengan pronomina demonstrativa. Keduanya berbeda dari segi fungsi masing-masing. Pronomina demonstrativa digunakan sebagai pengganti nomina, sedangkan adjektiva demonstrativa sebagai keterangan penunjuk terhadap kata/frase di depannya. Dalam hubungan ini, keterangan penunjuk tidak mengharuskannya berkategori adjektiva. Hal demikian menunjukkan terdapatnya kesepadanan dengan pendapat Diessel (Huang, 2007:151) tentang adanya determinator demonstrativa (demonstrative determiners) untuk maksud adjektiva demonstrativa. Adapun adverbia demonstrativa dimaksudkan untuk ekspresi lingual yang menunjukkan lokasi sesuatu atau objek dalam hubungannya dengan partisipan tutur. Sebutan lain, sebagai informasi aditif, untuk demonstrativa jenis terakhir ini adalah 'adverbia lokatif yang deiktis' (deictic adverbs of space) (Huang, 2007:151).

Selanjutnya, adverbia demonstrativa yang ditemukan dibedakan dengan mengacu kepada pembagian yang dikemuka- kan oleh Sudaryat (2009:123). Dari pembagian tersebut, masing-masing bagian yang tergolong ke dalam jenis adverbia demonstrativa ada yang bersifat statis, dan ada pula yang dinamis. Adverbia demonstrativa disebut bersifat statis jika hanya menggambarkan hal yang tidak bergerak. Kemudian, disebut bersifat dinamis jika menggambarkan adanya gerakan. Gerakan dimaksud ada yang menyiratkan ke tempat tujuan dan ada pula yang menyirakan dari tempat asal (Lyons, 1977:694; Purwo, 1984:39).

\section{METODE}

Penelitian ini menggunakan metode kualitatif dengan pengandalan pengambilan data berciri natural setting. Pemilihan metode sesuai dengan fokus penelitian yang terkait dengan pemerian fenomena bahasa. Data penelitian bersumber dari lapangan tempat penutur bahasa melakukan aktivitas sehari-hari. Pemerolehan data dengan cara ini dianggap relevan karena fenomena kebahasaan yang dikaji pemunculannya terjadi pada konteks yang alamiah. Bogdan \& Biklen (Aminuddin, 1990:15) menjelaskan bahwa fenomena deiksis pemunculan secara penuh lebih memungkinkan terjadi dalam konteks alamiah daripada di tempat atau lokasi yang telah direkayasa sebelumnya. Penelitian berciri natural setting dilakukan dengan mengambil bahasa yang digunakan masyarakat dalam kehidupan sehari-hari, seperti di tempat kerja, waktu istirahat, belanja di pasar; bukan bahasa yang digunakan pada upacara-upacara resmi, seperti upacara perkawinan, kematian, di lembaga pendidikan, dan institusi lainnya.

Subjek penelitian ini adalah penutur bahasa Mandailing yang bertempat tinggal di Mandailing. Sumber pemerolehan data tidak terikat pada satu dua penutur tertentu, tetapi dari penutur lain yang dalam waktu spontan atau kebetulan memunculkan fenomena penggunaan 
tuturan-tuturan yang di dalamnya terdapat unsur demonstrativa. Dengan demikian jumlah subjek untuk pengambilan data percakapan tidak mengikat berapa jamaknya. Yang terpenting adalah tercapainya kecukupan data yang diperlukan untuk menjawab fokus penelitian. Untuk subjek sebagai informan, diambil tiga orang yang berumur di atas 40 tahun. Pemilihan tersebut dengan pertimbangan bahwa informan dapat memberikan informasi penggunaan bahasa dan budaya masyarakat Mandailing.

Daerah Mandailing yang dimaksud sebagai lokasi penelitian ini adalah Kabupaten Mandailing-Natal (Madina) selain Natal, dengan titik pengamatan di tiga tempat, yaitu: (1) Siabu dan sekitarnya sebelah utara, (b) Penyabungan dan sekitarnya di bagian tengah, dan (c) Kotanopan dan sekitarnya di sebelah Selatan. Pemilihan ketiga lokasi tersebut didasarkan pada tingkat konsentrasi masa penduduknya yang lebih tinggi dari lokasi lain di wilayah yang sama.

Data penelitian meliputi data lisan berupa tuturan atau bagian tuturan dari berbagai peristiwa tutur dan informasi atau keterangan langsung secara lisan berkenaan dengan deiksis tempat (demonstrativa) pada khususnya dan tentang budaya pada umumnya. Pengumpulan data menggunakan metode wawancara dan pengamatan langsung pengggunaan bahasa disertai dengan pencatatan lapangan. Data diperoleh dengan menggunakan metode simak disertai perekaman (Sudaryanto, 1986:62).

Ada kalanya fenomena kehadiran unsur demonstrativa terjadi dalam peristiwa tutur spontan yang sifatnya sporadis dan singkat pada waktu dan tempat yang berbeda-beda. Agar fenomena penggunaan demonstrativa seperti itu tidak terabaikan dan tetap menjadi bagian dari data penelitian, dilakukan upaya pencatatan dengan hanya mengambil tuturan-tuturan singkat berupa kalimat atau frase yang di dalamnya terkandung demonstrativa yang dimaksudkan.

Analisis data dilakukan dengan tiga tahapan, yaitu: (1) reduksi data (data reduction), (2) penampilan data (data display), dan (3) pengambilan kesimpulan/verifikasi (conclusion drawing/ verification) (Miles \& Huberman, 1984:22-23). Ketiga tahapan bersifat inter-relasi sebagai bagian dari keseluruhan proses analisis. Berdasarkan pemahaman teori demonstrativa, upaya pereduksian data dilakukan dengan me-review secara elaboratif catatan dan rekaman yang memuat kalimat, frase, yang di dalamnya terdapat unsur dan penggunaan demonstrativa. Kegiatan tahap ini berkaitan dengan identifikasi dan kategori unsur demonstrativa sesuai teori yang digunakan.

Kegiatan penampilan data dilakukan dengan cara mengekstrak data yang diperoleh serta mengategorisasikannya, sehingga terlihat hubungan antarkategori di antara jenis-jenis demonstrativa yang ditemukan dalam bahasa Mandailing. Pada tahap pengategorisasian data juga diambil simpulan sementara mengenai pola hubungan antarkategori di antara jenis-jenis demonstrativa tersebut, dengan memperhatikan kecenderungan, sifat, serta kaitannya dengan data dari kategori lainnya. Uji data yang telah dikategorisasikan tetap dilakukan selama penelitian dan menunjukkannya kepada informan, apakah data berupa demonstrativa yang dikategorisasikan dan penggunaannya sudah sesuai dalam bahasa Mandailing. Dukungan data lapangan dalam pengujian data dan pembenaran dari informan terhadap data yang ditunjukkan dijadikan dasar untuk menampilkannya (data display) dalam bagan sistem demonstrativa bahasa Mandailing.

Selanjutnya, dalam pengambilan simpulan/verifikasi, diuji kembali simpulan sementara yang diperoleh dengan cara mendasarkan pada fakta penggunaan di lapangan serta pembenaran dari infor- 
man. Diperolehnya dukungan data dari lapangan dan adanya pembenaran dari informan terhadap simpulan sementara yang dibuat, dijadikan dasar penulisan laporan penelitian.

\section{HASIL DAN PEMBAHASAN}

Sesuai fokus penelitian, ditampilkan bentuk-bentuk demonstrativa yang terdapat dalam bahasa Mandailing. Keseluruhannya kemudian dibagi ke dalam tiga kategori berdasarkan pembagian jenis demonstrativa yang dikemukakan oleh Levinson (2004:42). Pembagian jenis demonstrativa Levinson tersebut dikombinasikan dengan pembagian Sudaryat (2009:123), yang membagi adverbia demonstrativanya lagi ke dalam tiga kategori. Hasil kombinasi kedua pembagian tersebut bersama bentuk-bentuk demonstrativa yang ditemukan mengisi masingmasing kategori disajikan pada Bagan 1. Berdasarkan urutan kategorinya, masingmasing bentuk ekspresi demonstrativa dijelaskan penggunaannya.

\section{Pronomina Demonstrativa}

Pronomina demonstrativa dimaksudkan untuk jenis yang fungsinya sebagai penunjuk dan pengganti nomina sekaligus, seperti this pada Look at this. Shannon (2013:16) mengategorikannya sebagai bentuk pronomina (pronominal forms) dengan ciri dapat hadir sebagai pengganti nomina tanpa tambahan penjelas; bukan sebagai modifikator pada kata/frase (Kridalaksana, 1982:108). Ada kalanya demonstrativa dapat hadir sebagai sebuah pronomina, yakni sebuah bentuk yang digunakan untuk menggantikan nomina atau frasa nomina (Klijs, 2013:7).

Dari pemahaman penjelasan tersebut, yang termasuk bentuk ekspresi pronomina demonstrativa dalam bahasa Mandailing adalah on 'ini', $i$ 'itu', dan odu 'yang sana'. Bentuk on lazim digunakan untuk mengacu objek tunggal yang lokasinya relatif dekat atau ada pada penutur. Penggunaan on pada (01), On ma lehen isia 'Inilah kasikan buat dia', dapat menjadi pengganti objek pada lokasi penuturnya berada. Tuturan (01) berisikan suruhan dari penutur kepada mitra tuturnya agar objek yang digantikan oleh on disampaikan kepada seseorang. Dalam konteks seperti itu, memungkinkan bahwa objek yang disampaikan berada dekat, misalnya, di depan penutur. Kondisi itu memungkinkan juga bahwa objek yang dimaksud ada pada diri, misalnya, yang di tangan penutur.

Ada kalanya bentuk on digunakan sebagai pengganti waktu kekinian bagi penutur pada saat tuturan. On, dalam konteks berbicara soal waktu, tidak dapat dimaknai seperti pada (01) yang, dalam bahasa Indonesia bermakna 'ini'. Dalam pembicaraan terkait waktu, seperti pada (02), Idia tarpainte hita be $i$, on naso ro dope ia 'Manalah dapat kita tunggu lagi, saat

\begin{tabular}{|c|c|c|c|c|}
\hline \multicolumn{5}{|c|}{ DEMONSTRATIVA } \\
\hline \multirow{3}{*}{ Pronominal } & \multirow{3}{*}{ Adjektifal } & \multicolumn{3}{|c|}{ Adverbial } \\
\hline & & \multirow{2}{*}{$\frac{\text { Statis }}{\text { Lokatif }}$} & \multicolumn{2}{|c|}{ Dinamis } \\
\hline & & & Tujuan & Asal \\
\hline on & - on & $i$ son & tu son & ngon on \\
\hline$i$ & $-i$ & $i s i$ & tu si & ngon $i$ \\
\hline$o d u$ & - odu & $i$ sodu & tu sodu & ngon odu \\
\hline
\end{tabular}

Bagan 1. Sistem Demonstrativa BM 
ini saja dia belum datang', on bermakna 'saat ini'.

Pronomina demonstrativa $i$ 'itu'. Pengacuan dengan $i$ dilakukan terhadap objek tunggal yang lokasinya relatif jauh dari penutur dan yang dekat atau ada pada mitra tutur. Penggunaan $i$ untuk mengacu kepada objek yang relatif jauh dari penutur dapat ditemukan, misalnya, pada tuturan seorang penghuni rumah, seperti pada (03), Gonti homu $i$ 'Kalian ganti itu!'), yang meminta mitra tuturnya untuk mengganti kaca jendela rumahnya yang baru saja pecah karena ulah yang dilakukan oleh mitra tutur. Dalam hubungan ini, $i$ pada (03), oleh penutur, digunakan untuk mengacu kepada objek (kaca jendela rumah) yang relatif jauh dari penutur. Untuk pengacuan dari penutur terhadap objek yang dekat atau berada pada mitra tutur, yang terdapat pada (04), I ma di ahu 'Itulah untukku', dapat dijadikan sebagai contohnya. Tuturan (04) dapat ditemukan, misalnya, sebagai respons kesetujuan penutur atas tawaran untuk menentukan pilihan di antara sejumlah kemungkinan objek di sekitar mitra tutur, termasuk yang berada di tangan mitra tuturnya.

Hal lain terkait dengan $i$ adalah bahwa $i$ digunakan untuk mengacu objek yang tidak terlihat, baik karena terhalang pandang maupun oleh adanya pengabstraksian terhadap objek yang kehadirannya telah diketahui secara bersama sebelum saat tuturan. Pengacuan terhadap objek yang terhalang pandang, misalnya, dapat ditemukan pada tuturan reaktif dari seorang penghuni rumah dalam merespons isyarat kedatangan tamu yang belum teridentifikasi (yang lagi berdiri di balik pintu), seperti pada (05), Ise de i'Siapakah itu?' Dalam konteks tuturan (05), $i$ digunakan untuk mengacu kepada objek (orang) yang relatif jauh dari penutur pada saat tuturan.

Dari konteks tuturan (05) terdapat dua kemungkinan mitra tutur bagi penu- tur, dan penentuan salah satunya dapat berimplikasi terhadap pemaknaan $i$. Kemungkinan pertama, penutur menjadikan penghuni lain dari rumah yang sama sebagai mitra tutur pada saat datangnya tamu. Kemungkinan kedua, penutur menjadikan tamu yang datang sebagai mitra tuturnya. Jika yang dijadikan sebagai mitra tutur pada saat itu adalah penghuni lain dari rumah yang sama, makna $i$ pada tuturan (05) adalah 'dia', dan apabila yang menjadi mitra tutur bagi penutur pada saat itu adalah tamu yang lagi berada di balik pintu, makna $i$ pada (05) adalah 'kamu/engkau' yang dalam bahasa Mandailing sama dengan homu (bentuk hormat pengganti ho untuk orang kedua tunggal).

Pengabstraksian dapat terjadi terhadap objek yang tidak terlihat karena faktor kejauhan atau objek yang dimaksud keberadaannya telah diketahui sebelumnya oleh penutur dan mitra tutur. Pengacuan terhadap objek semacam itu juga tetap dengan menggunakan $i$. Jarak relatif objek yang diacu dalam situasi demikian tidak lagi menjadikan lokasi penutur saja sebagai pusat pengacuan, tetapi dengan menginklusifkan lokasi mitra tutur di dalamnya. Dalam konteks seperti itu, contoh (05) dapat juga digunakan apabila objek yang diacu dengan $i$ itu berupa orang yang kehadirannya telah diketahui sebelumnya oleh penutur dan mitra tutur.

Pronomina demonstrativa odu 'yang sana'. Bentuk odu digunakan untuk mengacu objek tunggal yang lokasinya jauh dari penutur dan mitra tutur. Faktor kejauhan antara objek yang diacu dengan menggunakan odu ke lokasi penutur dan mitra tutur membuat perlunya sertaan isyarat dalam penggunaannya. Dalam konteks tutur (06), Inda i balokta, odu do 'Bukan itu batas kita, (tetapi) yang sana', seorang penutur hendak menunjukkan tanda batas kebunnya dengan mitra tutur. Tuturannya pada (06) menunjukkan adanya isyarat dari penutur untuk me- 
ngarahkan pandangan mitra tuturnya ke objek yang dimaksud.

Odu dapat juga diacukan terhadap objek tunggal tanpa isyarat. Cara seperti itu lazimnya dilakukan apabila objek yang diacu tersebut berupa orang ketiga tunggal yang kehadirannya tidak ada di lokasi penutur dan mitra tutur pada saat tuturan. Dalam hubungan ini, terdapat pengabstraksian objek yang telah diketahui secara bersama sebelumnya oleh penutur dan mitra tutur. Pengetahuan mitra tutur sebelum saat tuturan terhadap objek yang dimaksudkan dapat dijadikan sebagai sebab tidak diperlukannya lagi isyarat untuk mengarahkan perhatian mitra tutur terhadap objek yang diacu oleh penutur dengan menggunakan odu .

Jika A, misalnya, mengetahui bahwa B tidak dapat masuk rumah karena adiknya $C$ yang lagi marah terhadapnya mengunci pintu dari dalam, menceritakan kejadian itu di hadapan mitra tutur pada kesempatan yang berbeda di tempat lain, tuturan seperti pada (07) dapat muncul dari A (sebagai penutur).

(07) Bo, inda ra $\left\{\begin{array}{l}\text { odu } \\ \text { ia } \\ \text { si C }\end{array}\right\}$ mambuka pintu bagas.

'(Jadi) tidak mau ( .......... ) membukakan pintu rumah.'

Pada tuturan (07), A mengacukan odu terhadap adik B (si C), yang tidak sudi membukakan pintu dari dalam rumah. Odu, yang diacukan terhadap objek berupa orang ketiga tunggal dalam konteks semacam itu dapat dimaknai dengan 'dia', sebagaimana pronomina ia dengan makna yang sama dalam bahasa Mandailing. Pemaknaan seperti itu dapat didasarkan pada kemungkinan dapatnya odu dan ia saling menggantikan dalam kerangka substitusi, seperti dibuktikan oleh contoh (07). Baik odu maupun ia pada tuturan
(07), acuannya, dalam konteks di atas, adalah si C.

\section{Adjektiva Demonstrativa}

Jika pronomina demonstrativa juga sekaligus sebagai pengganti nomina, adjektiva demonstrativa merupakan keterangan penunjuk yang hadir bersama nomina atau frasa nomina (Klijs, 2013:7). Keterangan penunjuk tidak mengharuskannya berkategori adjektiva. Dapat juga berupa pemarkah definit/takrif terhadap objek yang diacu. Hal demikian menunjukkan terdapatnya kesepadanan dengan pendapat Diessel (Huang, 2007:151) tentang adanya determinator demonstrativa (demonstrative determiners) untuk maksud adjektiva demonstrativa (demonstrative adjektives). Sebagai contoh, menurut Klijs, adalah that pada I would like that ice-cream.

Untuk membedakannya dengan bentuk pronomina demonstrativa, digunakan tanda garis hubung (-) di depan bentuk adjektiva demonstrativa, yang menandakan adanya hubungan atributif dengan kata/frase di depannya.

Dalam liputan jenis adjektiva demonstrativa bahasa Mandailing, terdapat tiga bentuk ekspresi demonstrativa, yaitu - on 'ini', - $i$ 'itu', dan - odu 'yang sana'. Bentuk - on digunakan untuk mengacu dan memberi keterangan terhadap dua kemungkinan kelas kata/frase. Kemungkinan pertama untuk nomina, dan yang kedua untuk adverbia. Apabila yang diacu dengan - on itu berkelas nomina, objek yang dimaksud lokasinya berada relatif dekat dengan penutur. Kedekatan objek terhadap penutur tidak mengharuskan adanya jarak antara pada keduanya. Dalam hubungan ini, - on dapat juga diacukan kepada objek berupa diri penutur sendiri atau objek yang menjadi tempat penutur berada pada saat tuturan. Perhatikan dan bandingkan nomina yang berada di depan - on pada (08). 
(08)

$$
\begin{aligned}
& \left\{\begin{array}{l}
\text { susui } \\
\text { na rara } \\
\text { ahu } \\
\text { sopo godang } \\
\text { bagas }
\end{array}\right\} \text { on } \\
& \left\{\begin{array}{l}
\text { sudut } \\
\text { yang merah } \\
\text { aku } \\
\text { balai pertemuan } \\
\text { rumah }
\end{array}\right\} \text { ini }
\end{aligned}
$$

Di antara kata/frase yang terdapat di depan - on pada (08), dua yang pertama terdiri dari objek nominal yang memiliki jarak antara, yang relatif dekat kepada penutur. Untuk yang ketiga, yang diacu adalah diri penutur sendiri. Mengenai dua yang terakhir pada (08), terdapat dua kemungkinan soal jarak terhadap penutur. Hal demikian disebabkan adanya tempat dalam objek yang dapat ditempati oleh penutur. Jika penutur melakukan pengacuan dengan - on dari luar objek yang diacu, terdapat jarak antara relatif dekat dari objek tersebut kepada penutur. Sebaliknya, apabila pengacuan dengan - on, oleh penutur, dilakukan dari dalam objek yang diacu, tidak terdapat jarak relatif dekat dari objek kepada penutur. Kemungkinan ada tidaknya jarak relatif dekat antara objek dengan penutur dalam pengacuan objek dengan -on, berlaku juga terhadap objek-objek yang memiliki tempat, yang dapat diisi atau dimasuki oleh penutur. Contoh lain adalah topas 'lumbung', guo 'gua', lobu 'kandang hewan'.

Kelas adverbia di depan - on liputannya terdiri dari adverbia tempat dan adverbia waktu. Apabila - on digunakan untuk mengacu kepada adverbia tempat, lokasi tempat yang dimaksud adalah lokasi penutur berada atau bagian dari lokasi yang relatif dekat dengan penutur. Contohnya dapat dilihat pada (09). Tuturan (09) memberi gambaran bahwa adverbia mana saja yang dituturkan dengan sertaan - on, penutur berada atau relatif dekat dengan lokasi yang dimaksudkannya.
(09) $\left\{\begin{array}{l}\text { i gincat } \\ \text { tu toru } \\ \text { ngon jolo }\end{array}\right\}$ on $\left\{\begin{array}{l}\text { di atas } \\ \text { ke bawah } \\ \text { dari depan }\end{array}\right\}$ ini

Apabila pengacuan dengan - on dilakukan terhadap adverbia waktu, lokasi waktu yang dimaksud adalah periode lalu yang relatif dekat dan meliputi waktu penutur pada saat tuturan dihasilkan. Pada tuturan (10), Parudan dope sannari on, nga piga halak tu kobun 'Sekarang masih penghujan, tidak banyak orang (pergi) ke kebun', maksud penutur dengan sannari on 'sekarang ini' adalah periode terjadinya musim penghujan yang sudah terjadi sejak hari tertentu pada waktu yang lalu bagi penutur hingga saat dia menghasilkan tuturan (10).

Bentuk $-i$. Ekspresi bentuk $-i$ digunakan untuk mengacu dan memberi keterangan terhadap dua kemungkinan kelas kata/frase. Kemungkinan pertama, $-i$ diacukan terhadap nomina, dan kemungkinan kedua, sebagai keterangan penunjuk terhadap adverbia. Kelas nomina, dalam hubungan ini, dibedakan antara yang kelihatan, dan yang tidak kelihatan, tetapi telah diketahui bersama keberadaannya sebelum saat tuturan. Dalam konteks tutur yang nominanya kelihatan, pengacuan dengan $-i$ dilakukan terhadap objek tunggal yang lokasinya relatif jauh dari penutur dan terhadap objek yang dekat atau ada pada mitra tutur. Penggunaan - $i$ untuk diacukan terhadap objek yang relatif jauh dari penutur dapat ditemukan, misalnya, pada tuturan seorang ayah yang menyuruh anak dewasanya untuk mengganti salah satu bola lampu rusak yang masih berada di langit-langit rumah mereka. Sebagai keterangan penunjuk terhadap objek (bola lampu (yang rusak)) yang relatif jauh dari tempatnya berada, sang ayah (penutur) menggunakan $-i$ untuk mengacu terhadap objek tersebut, seperti terdapat pada (11), Gonti jolo bola lampu $i$ 'Ganti dahulu bola lampu itu'. Bentuk - $i$ pada (11) berfungsi (digunakan) 
sebagai keterangan penunjuk terhadap objek nominal (bola lampu).

Penggunaan $-i$ untuk diacukan terhadap objek yang relatif jauh dari penutur menyebabkan tertutupnya kemungkinan untuk mengacukan $-i$ terhadap penutur atau lokasi tempat penutur berada pada saat tuturan. Perhatikan contoh (12). Objek nominal pertama pada (12), yaitu sitarika 'gosokan' (objek yang kelihatan), dapat diacu dengan $-i$ karena lokasinya berada pada jarak relatif jauh dari penutur. Kata nominal kedua pada (12), yaitu ahu 'aku', tidak dapat diacu dengan menggunakan - $i$ karena $a h u$ adalah penutur, yang tidak dapat dikatakan jauh dari dirinya sendiri. Demikian juga halnya dengan kata/frase ketiga, jugukankon 'tempat dudukku ini', tidak dapat diacu dengan $-i$, yang menyatakan relatif jauh, selagi penuturnya masih menempati 'tempat duduknya' tersebut. Pengacuan dengan menggunakan $-i$ terhadap jugukankon baru berterima apabila penuturnya beranjak dan tidak lagi berada pada tempat duduknya tersebut.

$$
\left\{\begin{array}{l}
\text { sitarika } \\
{ }^{*} \text { ahu } \\
{ }^{*} \text { jugukankon }
\end{array}\right\} \text { i ma pature. }
$$

$$
\text { ' ( ................... }) \text { itulah urus/betulkan.' }
$$

Terhadap objek nominal yang dekat atau berada pada mitra tutur, contoh pengacuannya dengan $-i$ dapat dilihat pada (13), Na gorsing i ma di ahu 'Yang kuning itulah untukku', yang dapat muncul dari seorang pembeli pakaian yang meminta penjualnya mengasikan dia 'pakaian yang berwarna kuning'. Dalam konteks seperti itu, objek yang dimaksud penutur adalah pakaian berwarna kuning yang relatif jauh dari penutur, tetapi relatif dekat atau ada pada mitra tutur. Dalam konteks tutur yang objek nominalnya tidak kelihatan, pengacuan terhadap objek yang dimaksud dapat juga dilakukan dengan menggunakan $-i$. Tuturan yang meng- gambarkan hal seperti itu dapat dilihat, misalnya, pada (14), Anggo inda dohot ko tu kobun, saba i ma pature 'Kalau engkau tidak ikut ke kebun, sawah itulah bereskan'. Tuturan (14) berasal dari seorang penutur yang mengajak mitra tuturnya untuk pergi bersama ke kebun mereka. Namun, karena sesuatu hal, mitra tutur tidak dapat pada kesempatan itu pergi bersama penutur.

Apabila diacukan kepada adverbia tempat, $-i$ merupakan keterangan penunjuk bahwa lokasi tempat yang dimaksudkan berada relatif jauh dari penutur pada saat tuturan. Adverbia tempat $i$ toru yang diacu dengan - $i$ pada (15), Na ijalahi mi nga dong $i$ son, ligi $i$ toru $i$ 'Yang engkau cari tidak ada di sini, cari di bawah itu', misalnya, menunjukkan bahwa lokasi 'di bawah' yang dimaksudkan adalah lokasi di bawah penutur, yang jaraknya relatif jauh dari penutur.

Adjektiva demonstrativa bentuk -odu 'sana'. Bentuk - odu pengacuannya dilakukan terhadap objek nominal tunggal yang lokasinya jauh dari penutur dan mitra tutur. Hal demikian mengimplikasikan bahwa-odu tidak dapat diacukan kepada, baik penutur dan mitra tutur maupun objek yang dekat atau berada pada penutur dan mitra tutur. Perhatikan contoh (16). Konteks tuturan (16) adalah, penutur meminta mitra tuturnya agar sudi mendekatkan beban yang dibawa mitra tutur ke arah objek tertentu (dalam kurung kurawal) yang jaraknya relatif jauh dari penutur dan mitra tutur. Pengacuan - odu terhadap dua objek yang pertama (sopo 'gubuk' dan susui 'sudut') adalah penggunaan yang berterima karena kedua objek tersebut lokasinya berada pada jarak jauh dari penutur dan mitra tutur. Terhadap kata ketiga, on 'ini' (sebagai pengganti objek nominal), pengacuan - odu tidak berterima karena objek ataupun lokasi yang digantikan oleh on pada (16) berada relatif dekat kepada penutur. Demikian juga terhadap dua kata yang terakhir (ahu 
'aku' dan ho 'engkau'), keduanya tidak dapat diacu dengan - odu. Sebabnya, ahu adalah penutur sendiri, sedangkan ho adalah mitra tutur yang dianggap selokasi dengan penutur.

(16) Padonok bobanmi tu $\left\{\begin{array}{l}\text { sopo } \\ \text { susui } \\ *_{o n} \\ *^{*} \text { ahu } \\ *_{h o}\end{array}\right\} o d u$.

'Dekatkan bebanmu itu ke (..... ) sana.'

\section{Adverbia Demonstrativa}

Pada adverbia demonstrativa, fungsi demonstrativa adalah sebagai keterangan tempat (locational adverbs) yang serempak kehadirannya dengan keberadaan verba. Klijs (2013:7) menjadikan here sebagai contohnya pada I left it here. Dalam bahasa Mandailing, adverbia demonstrativa merupakan gabungan antara preposisi dan demonstrativa. Di samping pronomina demonstrativa on, $i$, odu, terdapat juga adverbia demonstrativa son 'sini', si 'situ', sodu 'sana' dalam jumlah yang sama. Masing-masing anggota dari kedua jenis demonstrativa ini juga dengan kepemilikan titik taut yang sama.

Son, si, sodu, sesungguhnya adalah bentuk alternan dari on, $i$, odu, setelah melalui proses morfofonemik bersyarat fonemis (Parera, 1983:35-6). Bentuk-bentuk son, si, sodu sendiri tidak dapat digunakan tanpa penggabungannya dengan preposisi. Syarat pemunculan son, si, sodu adalah apabila preposisi yang digabungkan dengan on, $i$, odu berupa vokal atau berakhir dengan vokal. Dari penggabungannya dengan $i$ 'di' (preposisi berupa vokal) diperoleh bentuk gabungan $i$ son 'di sini', $i$ si 'di situ', $i$ sodu 'di sana'. Dari penggabungannya dengan $t u$ (preposisi berakhir vokal) diperoleh bentuk gabungan $t u$ son 'ke sini', tu si 'ke situ', tu sodu 'ke sana'; sedangkan dari penggabungannya dengan ngon (preposisi berakhir konso- nan) diperoleh ngon on 'dari sini', ngon $i$ 'dari situ', ngon odu 'dari sana'.

Di antara adverbia demonstrativa tersebut ada yang dapat disebut bersifat statis karena menggambarkan hal yang tidak bergerak. Yang tergolong ke dalamnya adalah adverbia demonstrativa berpreposisi $i$ 'di'. Ada yang disebut bersifat dinamis karena menggambarkan adanya gerakan. Gerakan dimaksud ada yang menyiratkan ke tempat tujuan, dan ada pula yang menyiratkan dari tempat asal. Dari dua jenis terakhir, yang menyiratkan tempat tujuan adalah yang menggunakan preposisi $t u$ ' $k e^{\prime}$, sedangkan yang menyiratkan tempat asal adalah yang menggunakan ngon 'dari' (Lyons, 1977:694; Purwo, 1984:39; Sudaryat, 2008:123). Kesembilan adverbia demonstrativa bentuk gabungan perolehan di atas disistematisasi dan disajikan pada Bagan 2.

\begin{tabular}{ccc}
\hline \multicolumn{3}{c}{ Adverbia } \\
\hline Statis & \multicolumn{2}{c}{ Dinamis } \\
\hline Lokatif & Tujuan & Asal \\
\hline$i$ son & tu son & ngon on \\
\hline$i$ si & tu si & ngon $i$ \\
\hline$i$ sodu & tu sodu & ngon odu \\
\hline Bagan 2 & Adverbia Demonstrativa BM
\end{tabular}

\section{Adverbia Demonstrativa Berpreposisi " $i$ "}

Yang termasuk ke dalam kategori adverbia demonstrativa ini adalah $i$ son, $i$ si, dan $i$ sodu (lihat bagan 2). I son adalah adverbia lokatif statis yang pengacuannya dilakukan terhadap lokasi yang relatif dekat atau yang menjadi tempat penutur berada pada saat tuturan. Pada tuturan (17), I son ma patibal tasmi 'Di sini saja letakkan tasmu itu', misalnya, lokasi yang dimaksud sebagai tempat peletakan objek oleh mitra tuturnya, berada pada jarak relatif dekat kepada penutur. Berbeda halnya dengan yang terdapat pada (18), 
I son sajo ia musor, nga jungada kaluar 'Di sini saja dia berkisar, tidak pernah (dia) keluar'. Jarak relatif dekat antara lokasi yang dimaksud kepada penutur, seperti pada (17), tidak ditemukan pada (18). Penutur sendiri pada (18) berada dalam lingkup terdapatnya tempat yang lebih luas daripada yang terdapat pada (17), yang boleh jadi adalah lingkungan bersama, seperti desa, kota, negara, tempat penutur ikut di dalamnya.

Dalam hal penutur menginklusifkan mitra tuturnya ke dalam lokasi yang ditempatinya, penggunaan $i$ son dapat juga dilakukan untuk pengacuan terhadap lokasi tempat keduanya berada, sebagaimana dapat dilakukan oleh penutur pada saat sebelum menginklusifkan mitra tuturnya ke dalam lingkup lokasi yang ditempatinya. Dalam hubungan ini, keberadaan mitra tutur bersama penutur dalam lokasi tuturan tidak menjadi sebab dilakukannya pengacuan dengan $i$ son terhadap lokasi tersebut. Penyebab $i$ son dapat diacukan terhadap lokasi tuturan tidak lain adalah karena keberadaan penutur di lokasi tersebut. Perhatikan contoh (19), I son ma hita marbuko dabo 'Di sini sajalah kita berbuka (puasa), ya'. Yang terdapat pada (19) adalah tuturan terhadap mitra tutur yang lagi berpuasa dari desa lain. Oleh karena menurut perkiraan penutur mitra tuturnya akan terlambat tiba pada saat berbuka puasa di desa yang dituju, penutur mengajak mitra tutur tersebut untuk berbuka bersama penutur. Lokasi penutur yang diacu dengan penggunaan $i$ son pada (19) adalah desa penutur, yang pada saat tuturan mitra tutur berada bersama penutur di lokasi (desa) yang dimaksud.

Adverbia demonstrativa bentuk $i$ si digunakan untuk mengacu kepada lokasi yang relatif jauh dari penutur. Penutur sendiri, dalam hubungan ini, tidak berada pada lokasi yang diacu. Perhatikan contoh (20), Ma i si bo manuk na ijalahi mi 'Sudah di situ ayam yang engkau cari'. Dari kon- teks tuturan (20), penutur menginformasikan kepada mitra tuturnya bahwa ayam yang lagi dicari oleh mitra tutur sudah terlihat olehnya di lokasi tertentu. Penutur mengacu lokasi tempat terlihatnya ayam tersebut dengan $i$ si. Lokasi yang diacu dengan $i$ si pada tuturan (20) adalah lokasi yang jaraknya kepada penutur relatif jauh, dan penutur sendiri tidak berada di lokasi tersebut.

Pengacuan dengan $i$ si dapat juga dilakukan terhadap lokasi yang menjadi tempat mitra tutur berada pada saat tuturan. Dalam hubungan ini, sebutan jarak relatif jauh antara lokasi yang dimaksud dengan penutur masih dapat digunakan karena penutur juga tidak berada pada lokasi mitra tutur yang dimaksud. Tuturan yang menggambarkan hal yang disebutkan berasal dari seorang penutur perokok yang lupa membawa korek api ke kebun. Di lokasi tertentu sepanjang perjalanan dia melihat seorang yang memungkinkan untuk ditanyakan apakah pada lokasi atau pada orang tersebut ada korek api. Penutur berjalan menuju orang tersebut, dan bertanya dengan menggunakan tuturan (21), Adong i si kayapi 'Ada di situ korek api?' Pengacuan dengan menggunakan $i$ si oleh penutur pada (21) adalah terhadap lokasi tempat mitra tutur (orang tersebut) berada pada saat tuturan. Memungkinkan juga bahwa acuan $i$ si pada (21) adalah mitra tutur, karena objek, yang ditanyakan (korek api), dapat juga berada pada saku atau tangan orang yang menjadi mitra tutur. Namun, kenyataan itu tidak dapat dijadikan dasar untuk mengatakan bahwa acuan $i$ si pada (21) bukan lokasi yang ditempati oleh mitra tutur karena objek yang ada pada diri mitra tutur tetap berada pada lokasi mitra tutur berada pada saat tuturan.

Ada kalanya terjadi penginklusifan mitra tutur oleh penutur ke dalam lingkup lokasi penutur, sehingga pengertian jarak relatif jauh yang terdapat pada $i$ si ialah jarak antara lokasi yang diacu kepada 
lokasi yang menjadi tempat penutur dan mitra tutur berada pada saat tuturan. Penginklusifan mitra tutur ke dalam lingkup lokasi yang sama dengan penutur semacam itu lazimnya terjadi pada pengacuan terhadap lokasi yang tidak kelihatan bagi penutur dan mitra tutur, tetapi telah diketahui bersama sebelumnya oleh kedua partisipan. Misalnya, penutur A menginformasikan kepada mitra tuturnya $\mathrm{B}$ bahwa seorang teman mereka lagi sakit dan tidak bisa keluar dari rumahnya. Mitra tutur B merespons penutur semula dengan menanyakan, dengan siapa si sakit berada di rumahnya. Acuan $i$ si pada (22) adalah lokasi (berupa rumah) yang tidak kelihatan oleh A dan B selaku mitra tutur dan penutur pada saat tuturan. Oleh karena B menginklusifkan A ke dalam lingkup lokasi B pada saat tuturan, maka jarak relatif jauh yang tersirat pada $i$ si dalam konteks tuturan (22) adalah jarak antara dari lokasi si sakit (rumahnya) ke lokasi penutur dan mitra tutur pada saat tuturan (22) dihasilkan.

Adverbia demonstrativa bentuk $i$ sodu 'di sana'. Pengacuan dengan $i$ sodu dilakukan terhadap lokasi yang letaknya jauh dari penutur dan mitra tutur, dan keduanya tidak berada pada lokasi yang dimaksud pada saat tuturan. Faktor kejauhan dari lokasi kedua partisipan (penutur dan mitra tutur) ke lokasi yang dimaksud oleh penutur membuat pengacuan dengan $i$ sodu lazimnya dilakukan dengan sertaan isyarat untuk mengarahkan pandangan mitra tutur ke lokasi yang diacu. Dari tuturan (23), Huida dope halahi nangkin i sodu bo 'Saya masih melihat mereka tadi di sana', penutur menggunakan isyarat dalam mengacu kepada lokasi tertentu, yang menjadi tempat terlihatnya objek (halahi) oleh penutur sebelum saat tuturan. Untuk menginformasikan di mana penutur melihat objek yang lagi dicari oleh mitra tutur, penutur meresponsnya dengan tuturan (23), yang di dalamnya terdapat adverbia demonstrativa bentuk $i$ sodu. Maksud $i$ sodu pada (23) adalah lokasi tertentu yang jaraknya jauh dari penutur dan mitra tutur.

\section{Adverbia Demonstrativa Berpreposisi " $t u$ "}

Dalam kelompok ini terdapat tiga adverbia demonstrativa, yaitu $t u$ son, $t u s i$, $t u$ sodu (lihat Bagan 2). Tu son merupakan adverbia demonstrativa yang menyiratkan gerakan ke arah lokasi yang relatif dekat atau yang menjadi tempat penutur berada pada saat tuturan. Dengan demikian, pada penggunaan $t u$ son terdapat gerakan tersirat yang menuju pusat deiksis. Tuturan pada (24), Na riburan i si, ro ho tu son 'Ribut kali di situ, datang (saja) ke sini', merupakan anjuran agar mitra tutur pindah tempat ke lokasi penutur berada disebabkan intensitas gangguan suara yang ada di lokasi mitra tutur. Berbeda dengan $t u$ son, adverbia demonstrativa tu si menyiratkan gerakan ke arah lokasi yang relatif jauh dari penutur atau ke lokasi mitra tutur berada pada saat tuturan. Untuk arah gerakan ke lokasi yang relatif jauh dari penutur, misalnya, dapat ditemukan dari seorang yang lagi menonton televisi yang menyuruh mitra tuturnya agar jangan meletakkan objek (barang) bawaannya di depan penutur karena dianggap mengganggu pandangannya. Sebagai lokasi alternatifnya, penutur menunjukkan sebuah lokasi lain yang akan dituju oleh mitra tutur untuk meletakkan objek bawaannya tersebut. Dalam tuturannya kepada mitra tutur, seperti pada (25), Papinda i tu si bo, targanggu ahu manonton 'Pindahkan dulu itu ke situ, terganggu saya menonton', terdapat adverbia demonstrativa $t u$ si yang acuannya adalah lokasi yang akan dituju oleh mitra tutur.

Penggunaan $t u s i$, yang menyiratkan gerakan ke arah mitra tutur, dapat ditemukan, misalnya, pada tuturan tanya penutur kepada mitra tuturnya apakah penutur boleh datang ke lokasi mitra tutur yang lagi diajak berbicara. Penutur, 
dalam mengacu ke lokasi mitra tutur yang berjarak relatif jauh dari penutur tersebut, menggunakan tu si dalam tuturannya pada (26), Roma ahu tu si 'Saya datang ke situ, (ya)?' Dalam hal lokasi yang hendak dituju tidak kelihatan dari lokasi penutur dan mitra tutur, tetapi telah diketahui secara bersama oleh keduanya, tu si merupakan pengacu terhadap lokasi yang relatif jauh dari lokasi bersama kedua partisipan. Contoh (27), Naron ro pe ahu tu si '(Biar) nanti saya datang ke situ', merupakan tuturan yang menggambarkan hal seperti itu.

Adverbia demonstrativa $t u$ sodu digunakan untuk mengacu terhadap lokasi tujuan gerakan yang jaraknya jauh dari lokasi penutur dan mitra tutur. Pada saat tuturan, penutur dan mitra tutur tidak berada di lokasi jauh yang dimaksud, seperti terlihat pada contoh (28), Ulang isi be, tu sodu homu main 'Jangan di situ lagi, ke sana kalian bermain'.

\section{Adverbia Demonstrativa Berpreposisi "ngon"}

Dalam kategori ini terdapat tiga anggota di dalamnya, yaitu ngon on, ngon $i$, ngon odu (lihat Bagan 2). Adverbia demonstrativa ngon on menyiratkan asal gerakan dari lokasi yang relatif dekat atau yang menjadi tempat penutur berada pada saat tuturan. Dalam hal yang dimaksud adalah lokasi penutur, pada ngon on terdapat penyiratan gerak meninggalkan pusat deiksis. Dalam konteks seperti itu, penggunaan ngon on oleh penutur ditemukan pada (29), Nga dong gunamu, morot ma ho ngon on 'Tidak berguna engkau, pergilah engkau dari sini', Ngon on pada (29) diacukan oleh penutur terhadap lokasinya (dapat berupa rumah ataupun desanya) yang akan ditinggal oleh mitra tutur. Jika dikaitkan dengan waktu, ngon on dapat dimaknai dengan 'dari waktu sekarang'. Dalam hubungan ini, on bermakna 'waktu sekarang'. Oleh karena on merupakan waktu kini bagi penutur pada saat tutur- an, ngon on dalam konteks waktu, dapat menyiratkan 'dari lokasi waktu penutur berada pada saat tuturan' yang akan ditinggalkan seiring dengan berjalannnya waktu. Perhatikan contoh (30), Ngon on tu pudi ni ari nga di ahu ia 'Dari sekarang hingga kelak saya tidak mau padanya'. Pada tuturan (30), penutur menggunakan ngon on untuk diacukan terhadap lokasi waktu kekiniannya, yang akan dilewatkan karena berjalannya waktu.

Adverbia demonstrativa ngon i. Pada ngon $i$ tersirat adanya asal gerakan dari lokasi yang relatif jauh dari penutur atau berasal dari lokasi mitra tutur berada pada saat tuturan. Dalam konteks seorang anak, melalui jendela rumah mereka, memanggil ayahnya yang baru keluar dan memberi tahu bahwa ayahnya lupa membawa satu anak kunci pintu rumah untuknya karena rumah hendak ditinggal kosong, sang ayah meresponsnya dengan kembali ke arah sang anak. Pada jarak yang relatif jauh, ayahnya, yang sudah dalam posisi bersiap, menyuruh lemparkan saja anak kunci pintu itu ke arah ayahnya, sehingga dia tidak perlu lagi datang masuk ke rumah untuk mengambilnya. Pada tuturan sang ayah, yang menyuruh lemparkan anak kunci pintu itu (lihat contoh (31), Ngon i ma timbungkon so husambut 'Lemparkan saja dari situ, biar saya sambut'), terdapat adverbia demonstrativa ngon i. Penutur (sang ayah) menggunakan ngon i pada (31) untuk diacukan kepada lokasi anaknya, yang merupakan sumber datangnya anak kunci pintu, dan jarak antara dari lokasi tersebut kepada sang ayah (penutur) relatif jauh.

Apabila lokasi asal gerakan yang disiratkan tidak kelihatan dari lokasi penutur dan mitra tutur, namun, oleh penutur dan mitra tutur telah diketahui secara bersama sebelumnya, ngon $i$ merupakan pengacu terhadap lokasi yang jaraknya relatif jauh dari lokasi bersama antara penutur dan mitra tutur. Contoh yang menggambarkan hal seperti itu terdapat pada (32), Ngon $i$ 
ma hita naron mulak 'Dari situlah kita pulang nanti'. Pengacuan ngon $i$ oleh penutur pada tuturan (32) maksudnya untuk rumah $\mathrm{C}$ yang akan menjadi asal gerakan keberangkatan nantinya setelah urusan selesai di lokasi tersebut (rumah C). Jarak antara rumah $\mathrm{C}$, yang belum kelihatan itu, berada relatif jauh dari lokasi penutur dan mitra tutur pada saat tuturan.

Terkait dengan waktu, ngon $i$ dapat dimaknai dengan 'dari waktu lampau'. Dalam hubungan ini, $i$ bermakna 'waktu lampau'. Oleh karena $i$ merupakan waktu lampau bagi penutur pada saat tuturan, ngon $i$ dalam konteks waktu dapat menyiratkan 'dari lokasi waktu lampau bagi penutur' yang telah ditinggalkan seiring dengan berjalannya waktu. Perhatikan contoh (33), Ngon i torus sannari nga tarida be ia 'Dari (waktu) itu sampai sekarang dia tidak kelihatan lagi'.

Adverbia demonstrativa ngon odu penggunaannya ditujukan untuk mengacu kepada lokasi yang menjadi asal gerakan yang jaraknya jauh dari lokasi penutur dan mitra tutur. Pada saat tuturan, penutur dan mitra tutur tidak berada pada lokasi jauh yang dimaksudkan. Penggunaan ngon odu pada (34), Ngon odu mada ro aek $i$ 'Dari sanalah datangnya air itu', berasal dari seorang yang menunjukkan kepada mitra tuturnya dari kejauhan lokasi yang menjadi sumber mata air di bagian hulu sungai. Tanpa harus pergi bersama ke lokasi tersebut, penutur, dari lokasi keduanya berada, melakukan pengacuan dengan menggunakan ngon odu terhadap lokasi sumber air yang dimaksud.

\section{SIMPULAN}

Dari hasil dan pembahasan yang dilakukan diperoleh simpulan sebagai jawaban terhadap masalah yang menjadi fokus dalam penelitian ini. Pertama, dalam bahasa Mandailing ditemukan 15 ekspresi lingual yang berfungsi sebagai demonstrativa (Bagan 1). Baik pronomina demonstrativa, adjektiva demonstrativa, maupun adverbia demonstrativa bersama sub-jenisnya, masing-masing memiliki tiga buah bentuk ekspresi. Setiap bentuk ekspresi yang ada dalam masing-masing jenis demonstrativa, secara horizontal, menginformasikan kesamaan jarak relatif antara penutur dengan objek yang diacu dengannya. Sebaliknya, secara vertikal, setiap bentuk ekspresi yang terdapat dalam masing-masing jenis demonstrativa menginformasikan perbedaan jarak relatif antara penutur dengan objek yang diacu dengannya.

Kedua, dalam bahasa Mandailing terdapat pembagian atas tiga jarak relatif dalam penggunaan demonstrativanya, yakni: (1) jarak relatif dekat kepada penutur, (2) jarak relatif jauh dari penutur tetapi dekat kepada mitra tutur, dan (3) jarak relatif jauh dari penutur dan mitra tutur. Masing-masing dari ketiga jarak tersebut diekspresikan pula melalui tiga unsur lingual yang memiliki kesepadanan bentuk dalam setiap jenis demonstrativanya. Hal demikian membuat adanya hubungan simetris antar sesama jenis demonstrativa yang ada dalam bahasa Mandailing. Pada masing-masingnya, secara berurut, terdapat unsur on, $i$, dan odu.

Ketiga, penutur yang berkomunikasi dengan menginklusifkan mitra tuturnya, pengacuan terhadap yang relatif dekat kepada keduanya diacu dengan menggunakan bentuk ekspresi demonstrativa berunsur on; yang relatif jauh dari keduanya diacu dengan yang berunsur $i$; yang jauh dari keduanya, di luar pengacuan dengan $i$, pengacuannya dilakukan dengan menggunakan bentuk ekspresi demonstrativa berunsur odu; dan untuk yang diabstraksikan oleh keduanya, pengacuannya dilakukan dengan menggunakan yang berunsur $i$. Penutur yang berkomunikasi dengan mengeksklusifkan mitra tuturnya, pengacuan terhadap yang relatif dekat kepada penutur diacu dengan menggunakan demonstrativa (berunsur) on; yang relatif jauh dari penutur dan 
dekat kepada mitra tutur diacu dengan menggunakan demonstrativa (berunsur) $i$; yang berada di luar pengacuan dengan $i$, pengacuannya dilakukan dengan menggunakan demonstrativa (berunsur) odu; dan untuk yang diabstraksikan, di luar pengacuan dengan on, pengacuannya dilakukan dengan menggunakan demonstrativa (berunsur) $i$.

\section{UCAPAN TERIMA KASIH}

Adalah hal yang tidak dapat dinafikan bahwa hasil penelitian ini tidak akan terwujud atas kerja sendiri. Ada yang dalam penyelesaiannya dapat dilakukan setelah lebih dahulu beroleh dana dan informasi, di samping yang dapat diselesaikan oleh penulis sendiri. Tulisan ini merupakan bagian dari hasil penelitian peneliti yang berjudul "Deiksis dalam Bahasa Mandailing". Biaya pelaksanaannya berasal dari sebagian alokasi beasiswa dari Universitas Sumatera Utara (USU). Untuk itu, terima kasih kepada USU atas bantuannya hingga terseleggaranya penelitian ini. Ucapan terima kasih kepada para penutur bahasa Mandailing dan informan yang terlibat dalam penelitian ini. Demikian juga pihak terkait lain, seperti jajaran editorial di Jurnal LITERA, yang membantu memberi koreksi dan saran agar terpenuhinya syarat kelayakan hasil penelitian ini dipublikasikan.

\section{DAFTAR PUSTAKA}

Aminuddin (Ed.). 1990. Pengembangan Penelitian Kualitatif dalam Bidang Bahasa dan Sastra. Malang: Yayasan Asih Asah Asuh.

Gawronska, M. 2007. “Do Different Demonstrative Systems Influence Distance Categorization in Geographical
Space? Cross-Linguistic Comparison: Polish and Spanish". In Psychology of Language and Communication. Vol. 11, No. 2. Poland: University of Warsaw. Huang, Y. 2007. Pragmatics. New York: Oxford University Press.

Jarbou, S.O. 2012. "Medial Deictic Demonstratives in Arabic: Fact or Fallacy". In Journal of Pragmatics. Vol. 22, No. 1, page 103-118.

Klijs, G. 2013. "The Use of Demonstratives in Dutch Telephone Conversations". Tesis. Utrecht: University of Utrecht.

Kridalaksana, H. 1982. Kamus Linguistik. Jakarta: Penerbit Gramedia.

Levinson, S.C. 1983. Pragmatics. London: Cambridge University Press.

Levinson, S.C. 2004. 'Deixis and Pragmatics' for Handbook of Pragmatics Nijmegen: University of Nijmegen.

Lyons, J. 1977. Semantics 2. Cambrige: Cambridge University Press.

Miles, M.B. \& A.M. Huberman. 1984. Qualitative Data Analysis. Beverly Hills, California: Sage Publication.

Parera, J.D. 1983. Pengantar Linguistik Umum: Bidang Morfologi (seri B). Ende: Penerbit Nusa Indah.

Purwo, B.K. 1984. Deiksis dalam Bahasa Indonesia. Jakarta: Penerbit Balai pustaka.

Shannon, S.S. 2013. "The Blackfoot Demonstrative System: Function, Form, and Meaning". Tesis. The University of Montana.

Sudaryanto. 1986. Metode Linguistik: Ke Arah Memahami Metode Linguistik. Yogyakarta: Gadjah Mada University Press.

Sudaryat, Y. 2009. Makna dalam Wacana: Prinsip-prinsip Semantik dan Pragmatik. Bandung: Yrama Widya. 